\title{
Discovery of a novel effect of electric field exposure on human plasma beta-endorphin and interleukin-12 levels: Insight into mechanisms of pain alleviation and defense against infection by electric field therapy
}

\author{
Yuzo Nakagawa-Yagi ${ }^{1 *}$, Hiroyuki Hara ${ }^{1}$, Yusuke Yoshida ${ }^{2}$, Atsushi Midorikawa ${ }^{3}$ and Akikuni Hara ${ }^{1}$ \\ ${ }^{1}$ Hakuju Institute for Health Science Co., Ltd., 37-5 Tomigaya 1-chome, Shibuya-ku, Tokyo 151-0063, Japan \\ ${ }^{2}$ Acel, Inc., SIC-1 1201, 5-4-21 Nishihashimoto, Midori-ku, Sagamihara, Kanagawa 252-0131, Japan \\ ${ }^{3}$ World Fusion Co., Ltd., 2-15-15 Nihonbashi Ningyo-cho, Shinsendo Bld 7F, Chuo-ku, Tokyo 103-0013, Japan
}

\begin{abstract}
Medical treatment using high-voltage electric potential (HELP) devices to generate an electric field (EF) is an alternative therapy commonly used in Japan, but the molecular mechanisms involved are poorly understood. Healthy human subjects were exposed to a single 15 min $18 \mathrm{kV}$ stimulation of $\mathrm{HELP}$, after which plasma concentrations of several peptide hormones and cytokines were examined at 0,15 , and 45 min time points using enzyme-linked immunosorbent assays (ELISA). $\beta$-Endorphin, alpha-melanocyte-stimulating hormone ( $\alpha$-MSH), glucagon-like peptide-1 (GLP-1), interleukin (IL)-4, IL-12, and interferon-gamma $(\mathrm{IFN}-\gamma)$ levels were significantly up-regulated after HELP exposure. Under these conditions, HELP exposure had no effect on corticotropin-releasing hormone (CRH), adrenocorticotropic hormone (ACTH), IL-6, or IL-10 levels. Because HELP exposure is known to induce up-regulation of cis-8,11,14-eicosatrienoic acid (dihomo- $\gamma$-linolenic acid; DGLA), we examined the effect of DGLA on $\beta$-endorphin secretion. In human epidermal keratinocytes, DGLA significantly induced the secretion of $\beta$-endorphins, but not $\alpha$-MSH. DGLA-induced $\beta$-endorphin secretion was sensitive to the G protein-coupled receptor (GPR) 40 antagonist GW1100. Our findings provide new insights into the molecular mechanisms of pain control and defense against infection induced by EF therapy.
\end{abstract}

\begin{abstract}
Abbreviations: ACTH: adrenocorticotropic hormone; $\alpha$-MSH: alpha-melanocyte-stimulating hormone; $\mathrm{CRH}$ : corticotropinreleasing hormone; DGLA: dihomo-gamma-linolenic acid; DHA: cis-4,7,10,13,16,19-docosahexaenoic acid; EF: electric field; EIA: enzyme immunoassay; ELISA: enzyme-linked immunosorbent assay; EMF: electromagnetic fields; GLP-1: glucagon-like peptide 1; GPR: G protein-coupled receptor; GW1100:1-(4-ethoxycarbonylphenyl)2-(4-fluorobenzylthio)-5-(2-ethoxy-5-pyrimidinylmethyl)-4pyrimidinone; HELP: high-voltage electric potential; IL: interleukin; IFN: interferon; NK: natural killer; OEA: oleoylethanolamide; POMC: proopiomelanocortin; TRPV1: transient receptor potential vanilloid 1
\end{abstract}

\section{Introduction}

A therapeutic device to expose the human body to highvoltage electric potential (HELP) was approved by the Ministry of Health, Labour and Welfare in Japan [1-3]. High-voltage electric field $(\mathrm{EF})$ therapy is reported to be an effective treatment for stiff shoulders, constipation, insomnia, and headaches [1-9]. Although the mechanisms of EF therapy are largely unknown, previous attempts to find an EF exposure-induced biomarker using non-targeted plasma metabolomics have led to the detection of the endogenous signaling molecule oleoylethanolamide (OEA), a putative agonist of multiple proteins, including peroxisome proliferator-activated receptor-alpha (PPAR- $\alpha$ ), G protein-coupled receptor (GPR) 119, GPR55, and the transient receptor potential vanilloid 1 (TRPV1) [10]. Endogenous peptide hormones have been suggested as candidate molecules that may represent an interface between symptoms and therapeutic target proteins. A recent study by Lauffer et al. reported that OEA increased GLP-1 secretion from intestinal enteroendocrine L-cells [11]. The observations of Lauffer $e$ al. led us to study the effect of HELP exposure on peptide hormone levels [11]. In this study, we investigated the levels of several peptide hormones using ELISA on plasma samples obtained from healthy subjects before and at different times $(0,15$ or $45 \mathrm{~min})$ following exposure to a single HELP stimulation. Here we report that plasma $\beta$-endorphin levels can be up-regulated by HELP exposure. To elucidate the mechanisms leading to the changes in $\beta$-endorphin levels, we examined the effect of DGLA in human keratinocytes, and showed that it induces the secretion of $\beta$-endorphins.

\section{Materials and methods}

\section{EF exposure}

The system used for EF exposure has been previously described [910]. The EF system was equipped with a transformer, a seat, and two

Correspondence to: Yuzo Nakagawa-Yagi, Ph.D, Hakuju Institute for Health Science Co., Ltd., 37-5 Tomigaya 1-chome, Shibuya-ku, Tokyo 151-0063, Japan, Tel : (+81)3-5478-8833; Fax : (+81)3-5478-9825; E-mail: yagi@hakuju.co.jp

Key words: pain, high-voltage electric potential, electric field therapy, $\beta$-endorphin, interleukin-12

Received: May 07, 2015; Accepted: May 14, 2015; Published: May 18, 2015 
Nakagawa-Yagi Y (2015) Discovery of a novel effect of electric field exposure on human plasma beta-endorphin and interleukin-12 levels: Insight into mechanisms of pain alleviation and defense against infection by electric field therapy

insulator-covered electrodes; one electrode was placed on a floor plate on which the subject's feet were located, and the other was above the head of the subject. EF generated by the HELP apparatus (Healthtron PRO-18T or HES-A30; Hakuju Institute for Health Science Co., Ltd., Tokyo, Japan) was created uniformly by a transforming $50 \mathrm{~Hz}$ alternating current at $18 \mathrm{kV}$ or $30 \mathrm{kV}$. The safety of this system for human use was established by the Japanese government in 1963.

\section{Subjects}

Ten healthy adults [5 males and 5 females; mean age $42.4 \pm 2.8$ years; mean body mass index (BMI) $\left.23.6 \pm 1.0 \mathrm{~kg} / \mathrm{m}^{2}\right]$ participated in experiment 1 (exposure condition: $18 \mathrm{kV}, 15 \mathrm{~min}$ ). Ten healthy adults ( 6 males and 4 females; mean age $45.9 \pm 2.9$ years; mean BMI $22.9 \pm 1.0 \mathrm{~kg} / \mathrm{m}^{2}$ ) participated in experiment 2 (exposure condition: $30 \mathrm{kV}, 15 \mathrm{~min})$. All experiments were performed in the morning and all participants signed an informed consent form after receiving verbal and written information regarding the study. All experiments were conducted in accordance with the Declaration of Helsinki and the study protocol was approved by the human ethics committee of Hakuju Institute for Health Science Co., Ltd. (Tokyo, Japan).

\section{Plasma preparation}

Blood samples were collected in vacutainer tubes coated with ethylenediaminetetraacetic acid (VP-NA070K; Terumo Corporation, Tokyo, Japan) and immediately centrifuged at $800 \times g$ for $5 \mathrm{~min}$ using a centrifuge to separate plasma from other cellular materials. Subsequently, plasma was transferred to a fresh eppendorf tube and stored at $-80^{\circ} \mathrm{C}$ until processed.

\section{ELISA/EIA assay}

Plasma levels of $\beta$-endorphin, $\alpha$-MSH, CRH, ACTH, GLP-1, IL-4, IL-6, IL-10, IL-12, and IFN- $\gamma$ were measured using a human $\beta$-endorphin, $\alpha-\mathrm{MSH}$, and GLP-1 ELISA kit from Cusabio Biotech (Wuhan, Hubei, China), a human CRH EIA kit, an ACTH ELISA kit from Cloud-Clone (Houston, TX), or a human IL-4, IL-6, IL-10, IL-12, and IFN- $\gamma$ ELISA kit from R\&D systems (Minneapolis, MN).

\section{Molecular modeling and docking study}

The X-ray crystal structure of GPR40 complexed with agonist TAK-875 (4PHU; Protein Data Bank Japan) was used for the molecule docking study. This docking study of the binding of DGLA to GPR40 was performed using the Surflex-Dock program included with the Sybyl-X2.0 software package (Tripos International, St. Louis, MO) $[10,12]$. The docking experiment was performed five times and yielded three docking positions.

\section{$\beta$-Endorphin secretion in human epidermal keratinocytes}

Human epidermal keratinocytes (Lonza, Basel, Switzerland) were cultured in KBM-Gold keratinocyte cell basal medium (Lonza) supplemented with $2 \mathrm{mM}$ L-glutamine and $10 \%$ fetal bovine serum (Lonza). In brief, $1.3 \times 10^{5}$ cells were seeded in the wells of 12 -well multiwall plates. After $24 \mathrm{~h}$, the medium was changed to fresh serumfree medium, and GW1100 was added to the cells. After $30 \mathrm{~min}$ in GW1100, DGLA was added. After $24 \mathrm{~h}$, the medium was saved for use in a $\beta$-endorphin ELISA.

\section{Chemicals}

cis-8,11,14-eicosatrienoic acid (DGLA), cis-4,7,10,13,16,19docosahexaenoic acid (DHA), and GW1100 were purchased from Cayman Chemical (Ann Arbor, MI).

\section{Statistical analysis}

The data was analyzed using Welch's $t$-test. A probability $(p)$ value $<0.05$ was considered statistically significant.

\section{Results}

Effect of HELP exposure on peptide hormones and cytokines in plasma from healthy humans at different time points following EF

There was a remarkable difference in peptide hormone levels before and after 15 minutes of $18 \mathrm{kV}$ HELP exposure (Table 1). Plasma GLP-1 concentrations significantly increased immediately after HELP exposure compared with levels prior to exposure (1.86-fold, $p=0.037$ ). Plasma $\beta$-endorphin concentrations increased significantly $15 \mathrm{~min}$ and 45 min after HELP exposure compared with levels prior to exposure (15 min: 6.78-fold, $p=0.030 ; 45$ min: 5.60-fold, $p=0.005$ ), while plasma $a-\mathrm{MSH}$ concentrations significantly increased at the $45 \mathrm{~min}$ time point after HELP exposure when compared with pre-exposure levels (1.46fold, $p=0.037)$. Under these conditions, HELP exposure did not affect the levels of CRH and ACTH. Furthermore, the effect of HELP on $\beta$-endorphin levels was also analyzed at $30 \mathrm{kV}$; a relative ratio of 45 min time point after/before was at $1.25(p=0.031)$.

Because the release of neuropeptides from peripheral nerve endings is thought to contribute to the modulation of cross-talk between the endocrine and the immune systems [13-15], we also examined the effect of exposure to $18 \mathrm{kV}$ HELP for $15 \mathrm{~min}$ on several cytokines (Table 1). Plasma IL-12 concentrations increased significantly immediately after HELP, as well as at 15 and $45 \mathrm{~min}$ time points after HELP exposure with when compared with pre-exposure levels (0 min: 2.05-fold, $p=0.042 ; 15 \mathrm{~min}$ : 1.90 -fold, $p=0.003 ; 45 \mathrm{~min}$ : 2.58 -fold, $p=0.002$ ). Plasma IFN- $\gamma$ concentrations significantly increased at the $15 \mathrm{~min}$ and 45 min time points after HELP exposure compared with levels prior to exposure (15 min: 2.00 -fold, $p=0.019 ; 45 \mathrm{~min}: 3.07$-fold, $p=0.0001$ ), and plasma IL-4 concentrations increased significantly 45 min after HELP exposure compared with pre-exposure levels (1.62-fold, $p=0.023$ ). Under these conditions, HELP exposure did not affect the levels of IL-6 and IL-10. Furthermore, the effect of HELP exposure on IL-12 was also investigated using treatment for $15 \mathrm{~min}$ at $30 \mathrm{kV}$; a relative ratio of 15 min time point after/before was at $2.49(p=0.003)$.

Table 1. Effect of HELP (18 kV; $15 \mathrm{~min})$ exposure on peptide hormones and cytokines in plasma from healthy humans at multiple time points.

\begin{tabular}{|c|c|c|c|c|}
\hline & Before & $\begin{array}{l}0 \text { min } \\
\text { After HELP }\end{array}$ & $\begin{array}{l}15 \text { min } \\
\text { After HELP }\end{array}$ & $\begin{array}{l}45 \text { min } \\
\text { After HELP }\end{array}$ \\
\hline & Mean $\pm \mathrm{SE}$ & Mean $\pm \mathrm{SE}$ & Mean $\pm \mathrm{SE}$ & Mean $\pm \mathrm{SE}$ \\
\hline & $\mathrm{n}=10$ & $\mathrm{n}=10$ & $\mathrm{n}=10$ & $\mathrm{n}=10$ \\
\hline \multicolumn{5}{|l|}{ Peptide hormones } \\
\hline$\beta$-Endorphin $(\mathrm{pg} / \mathrm{mL})$ & $48 \pm 20$ & $217 \pm 77$ & $327 \pm 108^{*}$ & $270 \pm 53^{*}$ \\
\hline$\alpha-\mathrm{MSH}(\mathrm{pg} / \mathrm{mL})$ & $386 \pm 50$ & $508 \pm 68$ & $563 \pm 83$ & $563 \pm 72^{*}$ \\
\hline $\mathrm{CRH}(\mathrm{pg} / \mathrm{mL})$ & $454 \pm 29$ & $454 \pm 37$ & $418 \pm 34$ & $443 \pm 37$ \\
\hline $\mathrm{ACTH}(\mathrm{pg} / \mathrm{mL})$ & $269 \pm 32$ & $265 \pm 55$ & $295 \pm 75$ & $314 \pm 55$ \\
\hline GLP-1 (ng/mL) & $1.46 \pm 0.36$ & $2.71 \pm 0.62 *$ & $1.87 \pm 0.41$ & $1.89 \pm 0.41$ \\
\hline \multicolumn{5}{|l|}{ Cytokines } \\
\hline IL-4 (ng/mL) & $235 \pm 23$ & $291 \pm 48$ & $238 \pm 27$ & $382 \pm 47^{*}$ \\
\hline IL-6 (pg/mL) & $6.43 \pm 0.81$ & $7.47 \pm 1.21$ & $6.17 \pm 0.70$ & $7.05 \pm 0.39$ \\
\hline IL-10 (pg/mL) & $1.07 \pm 0.19$ & $1.06 \pm 0.15$ & $1.14 \pm 0.36$ & $1.43 \pm 0.28$ \\
\hline IL-12 (ng/mL) & $443 \pm 62$ & $909 \pm 186^{*}$ & $839 \pm 62 * *$ & $1142 \pm 165^{* * *}$ \\
\hline IFN- $\gamma(\mathrm{pg} / \mathrm{mL})$ & $1.73 \pm 0.26$ & $2.81 \pm 0.59$ & $3.47 \pm 0.52^{*}$ & $5.30 \pm 0.71 * *$ \\
\hline
\end{tabular}

${ }^{*} p<0.05$ compared with before. ${ }^{* *} p<0.01$ compared with before. 


\section{Docking of DGLA on GPR40}

Acute EF exposure is known to induce a notable increase in plasma DGLA levels in healthy subjects [10]. DGLA is known to activate GPR40 in HEK293 cells stably expressing GPR40 [16]. Therefore, we hypothesized that the increased plasma DGLA levels following EF exposure might be linked to changes in $\beta$-endorphin levels. Thus, we carried out a binding study using Sybyl-X2.0 software to explore the interactions of DGLA with the active site of GPR40. As shown in Figure 1, DGLA formed hydrogen bonds with Tyr91, Arg183, and Arg258, indicating that DGLA can bind to GPR40.

\section{Effect of DGLA on $\beta$-endorphin secretion in human epidermal keratinocytes}

In order to determine whether the docking of DGLA on GPR40 can induce a change in cellular function, we investigated the effect of DGLA on $\beta$-endorphin secretion using human epidermal keratinocytes. Human keratinocytes were treated with DGLA, and the secretion of $\beta$-endorphin was measured using ELISA $24 \mathrm{~h}$ later. As shown in Figure $2 \mathrm{a}$, DGLA increased $\beta$-endorphin secretion into the culture media in a dose-dependent manner. Under these conditions, exposure of the cells to $30 \mu \mathrm{M}$ of cis-4,7,10,13,16,19-docosahexaenoic acid (DHA) did not affect the secretion of $\beta$-endorphin (1.12-fold, $p=0.252)$; DHA (100 $\mu \mathrm{M})$ also examined, but it was itself cytotoxic (data not shown).

To determine the specificity of DGLA, we next examined the effect of DGLA on the secretion of a-MSH. DGLA had no effect on $a-\mathrm{MSH}$ secretion at any concentration tested (Figure $2 \mathrm{~b}$ ). Under these condition, exposure of the cells to $30 \mu \mathrm{M}$ of DHA did not affect the secretion of $\alpha$-MSH (0.99-fold, $p=0.154)$.

We then evaluated whether the GPR40 antagonist GW1100 could attenuate the effect of DGLA-stimulated $\beta$-endorphin secretion. The stimulating effect by DGLA $(30 \mu \mathrm{M})$ was almost completely abolished by $10 \mu \mathrm{M}$ GW1100 (Figure 2c).

\section{Discussion}

The present results indicate clearly that acute EF exposure affects plasma $\beta$-endorphin levels in healthy human subjects. $\beta$-Endorphin, $\alpha-\mathrm{MSH}$, and ACTH are reported to be the cleavage products of a precursor peptide proopiomelanocortin (POMC) in the hypothalamuspituitary gland system [17]. However, our findings show that EF exposure did not change ACTH or $\mathrm{CRH}$, which is an endogenous stimulator of ACTH secretion at the paraventricular hypothalamic nucleus. Interestingly, POMC in epidermal keratinocytes have also been suggested play a key role in the blood levels of $\beta$-endorphins [1819]. Indeed, a recent study has shown that plasma $\beta$-endorphin levels can be elevated by low-dose UV exposure [19]. Moreover, Khodorova et al. have reported that there is a new peripheral endogenous analgesic a

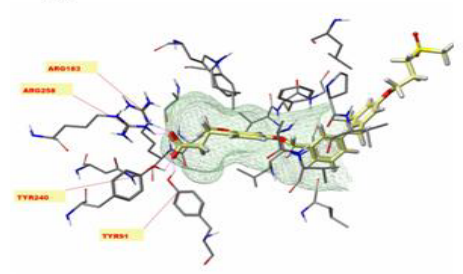

b

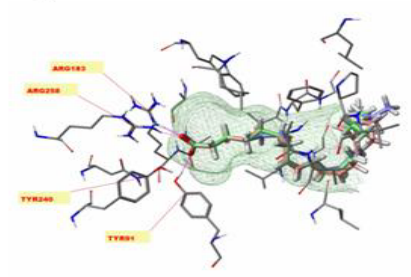

Figure 1. View of the conformation of DGLA docked in the GPR40 active site (a) Binding mode of TAK-875 in GPR40. (b) Binding mode of DGLA in GPR40. a

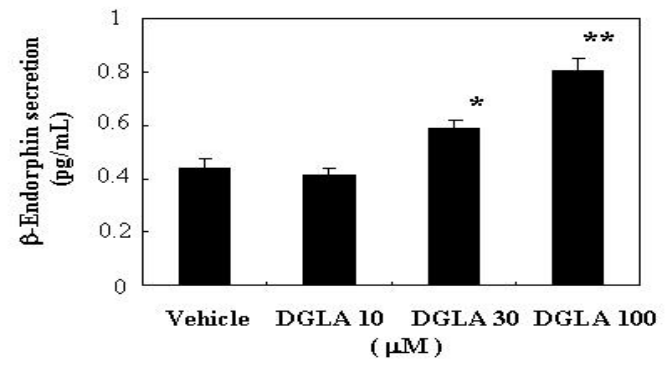

b

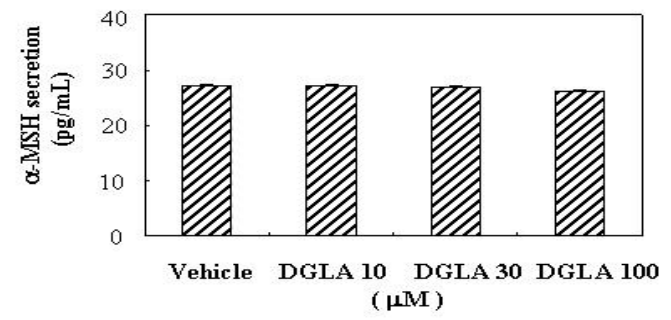

$\mathbf{C}$

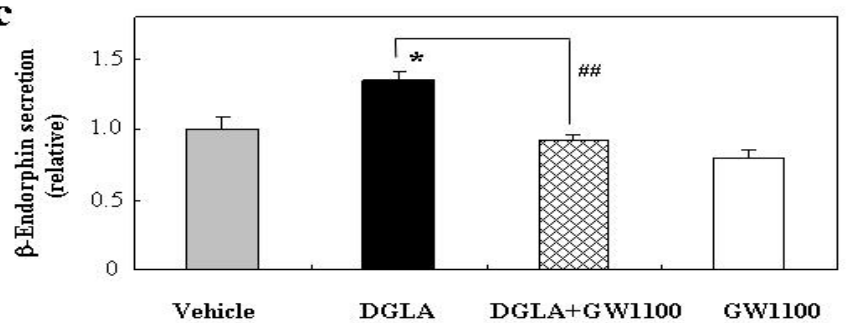

Figure 2. Effect of DGLA on $\beta$-endorphin secretion in human epidermal keratinocytes (a) Concentration dependence for DGLA-induced changes in $\beta$-Endorphin secretion. The cells were incubated for $24 \mathrm{~h}$ with either DGLA $(10-100 \mu \mathrm{M})$. (b) Effect of DGLA on $\alpha$-MSH secretion in human epidermal kerachinocytes. The cells were incubated for $24 \mathrm{~h}$ with either DGLA $(10-100 \mu \mathrm{M})$. (c) The effect of the GPR40 antagonist GW1100 on DGLA-induced activation of $\beta$-endorphin secretion. GW1100 $(10 \mu \mathrm{M})$ was added to cultured cells 30 min prior to and during $30 \mu \mathrm{M}$ DGLA incubation for $24 \mathrm{~h}$. Results are presented as mean $\pm \operatorname{SEM}(\mathrm{n}=5)$. ${ }^{*} p<0.05,{ }^{* *} p<0.01$, \#\# $p<0.01$.

circuit that can induce the release of $\beta$-endorphins from keratinocytes [20]. Thus, keratinocyte-derived $\beta$-endorphins may affect, at least in part, on up-regulation of plasma $\beta$-endorphin levels induced by EF exposure.

In humans, four free fatty acid (FFA) receptors have been identified: GPR40 (FFA1 receptor), GPR43 (FFA2 receptor), GPR41 (FFA3 receptor), and GPR120 (FFA4 receptor) [21]. An omega-6 fatty acid, cis-8,11,14-eiocosatrienoic acid (DGLA), is reported to be an endogenous ligand of GPR40 [16]. We have previously shown that acute EF exposure induces an increase in plasma DGLA levels of approximately 1.4-fold [10]. When considering the role of DGLA in changes in the plasma levels of $\beta$-endorphin, Nakamoto recently reported that intracerebroventricular injection of the GPR40 agonist GW9508 induces $\beta$-endorphin release in the arcuate nucleus of mice [22]. GPR40 is expressed by human epidermal keratinocyte cell lines [23], and in the present study, DGLA induced $\beta$-endorphin secretion by human epidermal keratinocytes in vitro, while DHA had no effect. This response was inhibited by the GPR40 antagonist GW1100. Briscoe et al. observed that treatment with either DGLA or DHA results in an increase in $\left[\mathrm{Ca}^{2+}\right] \mathrm{i}$ in HEK293 cells stably expressing GPR40 [16], with $\mathrm{pEC}_{50}$ values of 5.14 and 5.37 for DGLA and DHA, respectively. This apparent discrepancy may result from either of the following; (i) differences in the detection system used for the functional assay: e.g., 
Nakagawa-Yagi Y (2015) Discovery of a novel effect of electric field exposure on human plasma beta-endorphin and interleukin-12 levels: Insight into mechanisms of pain alleviation and defense against infection by electric field therapy

the ability to increase intracellular calcium versus the ability to increase $\beta$-endorphin secretion; or (ii) differences in the cell culture systems: e.g., human embryonic kidney 293 cells versus human epidermal keratinocytes.

Molecular computational modeling analysis showed that DGLA can bind to GPR40 in its active site, in a manner similar to TAK-875 [24]. DGLA binding to GPR40 was found to be stabilized through the formation of hydrogen bonds with Tyr91, Arg183, and Arg258, whereas a previous study of GPR40 with the agonist GW9508 reported hydrogen bonding to Asn244 and Ser247 [25]. This discrepancy may result from differences in the model systems; e.g., $4 \mathrm{PHU}$ (the crystal structure of human GPR40 bound to the allosteric agonist TAK-875) versus 1GZM (the structure of bovine rhodopsin in a trigonal crystal form).

Dietary fat is reported to be responsible for the release of $\beta$-endorphins in the serum and cerebrospinal fluid of rats [26]. We have recently found using non-targeted metabolome analysis that an increase in plasma DGLA levels elicited by EF exposure [10]. Thus, upregulation of plasma DGLA levels by EF exposure might involve, at least in part, the GPR40 signaling cascade. It is reasonable to speculate that EF exposure might alleviate pain through the up-regulation of $\beta$-endorphins. Shinba et al. reported that EF treatment for 3-4 weeks reduced the visual analog scale value for pain in chronic pain with no obvious underlying disease [9]. Although repetitive EF treatment was not performed in the present study, EF therapy may induce analgesia, at least in part, through the activation of opioid receptors by $\beta$-endorphins. Further studies to elucidate the effect of EF on endogenous DGLA $/ \beta$-endorphin-dependent signaling pathways and how this affects therapeutic interventions are therefore necessary.

Our findings show that several cytokines, including IL-12 and IFN- $\gamma$, are up-regulated by acute EF exposure. To date, research regarding the effect of EF exposure on cytokines is scarce. Most of the published studies were carried out using exposure to electromagnetic fields (EMF). Salehi et al. reported a decrease of IL-12 levels in the serum of rats after exposure to extremely low-frequency EMF ( $2 \mathrm{~h} /$ day for 3 months) [27], while Selmaoui et al. reported that acute EMF exposure increased IL- 6 levels in the serum of healthy young humans [28]. In contrast, we found that EF exposure led to up-regulation of the Th1 cytokines IL-12 and IFN- $\gamma$, but not the Th17 cytokine IL-6, suggesting that EF exposure might involve, at least in part, cell-mediated immunity. Baldridge et al. have recently reported that hematopoietic stem cells are activated by IFN- $\gamma$ in response to chronic infection [29]. There is also evidence that $\beta$-endorphins at concentrations between 10 ${ }^{10}$ and $10^{-13} \mathrm{M}$ have a stimulating effect on human natural killer (NK) cell activity [30]. Thus, it is conceivable that the increase in plasma IL12 and IFN- $\gamma$ levels is, at least in part, responsible for the improvement seen in patients with tuberculosis who undergo EF treatment [31]. However, it is unclear at present whether the changes in cytokine levels can be attributed to macrophages, lymphocytes, or NK cells. Further studies are needed to clarify the cytokine signaling pathways induced by EF exposure, and how this might affect the prevention of infection.

In conclusion, acute EF exposure induced notable effects on plasma $\beta$-endorphin levels in healthy subjects. In human epidermal keratinocytes, $\beta$-endorphin secretion induced by DGLA was sensitive to the GPR40 antagonist GW1100. Our findings not only help elucidate the molecular mechanisms of pain alleviation induced by EF therapy, but may also be important to the development of alternative medicine strategies.

\section{Competing interests}

YN-Y, HH and AH are employed by Hakuju Institute for Health Science Co., Ltd., YY is employed by Acel Inc., and AM is employed by World Fusion Co., Ltd.. All other authors have no competing interests.

\section{Authors' contributions}

YN-Y designed and supervised the research, and wrote the manuscript. $\mathrm{YN}-\mathrm{Y}, \mathrm{HH}$, and $\mathrm{AH}$ performed the $\mathrm{EF}$ exposure and biochemical experiments. YY performed the cell culture experiment. AM performed the molecular modeling. All authors read and approved the final version of this manuscript.

\section{Acknowledgement}

We are grateful to Dr. Makoto Kikuchi (Professor Emeritus, National Defence Medical College, Japan) for his encouragement.

\section{References}

1. Hara H (1961) On the effect of AC. electrostatic high voltage potential load upon the blood-electrolytes (in Japanese). Niigata Medical J 75: 265-273.

2. Ito F, Furuya K (1981) The effect of high voltage alternating current upon a human body the change of blood pressure, endocrine system and serum lipids (in Japaneses). $J$ Jpn Sci Balneol Climatol Phys Med 45: 6-17.

3. Ito F, Furuya K (1981) The effect of high voltage alternating current upon a human body the change of blood pressure, endocrine system and serum lipids (in Japaneses). $J$ Jpn Sci Balneol Climatol Phys Med 45: 6-17.

4. Nawarat S, Iomsai K, Jantanam P, Kauengtip Y (1999) Effects of electrical Healthtron on curing of non-communicable diseases: Casa study of Banlad hospital Petchaburi province (in Thai). Region 4 Medical J 18: 139-149.

5. Ito F (2000) The role of electric field therapeutic device (Healthtron) in the therapy of acute low back pain (in Japanese). J Jpn Sci Balneol Climatol Phys Med 63: 127 -137.

6. Siripanichgon K, Otrakul A, Suparp J, Sirikulchayanonta C, Charupoonphol P (2000) Clinical observation of Healthtron therapy (in Thai). J Public Health (Bangkok) 30 19-29.

7. Sirikulchayanonta C, Siripanichgon K, Otrakul A, Suparp J, Charupoonphol P (2001) The effect of Healthtron on serum lipid levels among the middle-aged: Preliminary report. J Public Health (Bangkok) 31: 63-70.

8. Owoeye O, Temiye E (2010) Therapeutic efficacy of attenuated high voltage Healthtron device on children with cerebral palsy. Nigerian J Medical Rehabilitation 15: 17-22.

9. Shinba T, Takahashi K, Kanetaka S, Nedachi T, Yamaneki M, et al. (2012) A pilot study on electric field therapy for chronic pain with no obvious underlying diseases (in Japanese). Soc Integrative Med Jpn 5: 68-72.

10. Nakagawa-Yagi Y, Hara H, Fujimori T, Yamaguchi T, Midorikawa A, et al. (2014) Non-targeted human plasma metabolomics reveals the changes in oleoylethanolamide, a lipid-derived signaling molecule, by acute exposure of electric field. Integr Mol Med 1: 29-37.

11. Lauffer LM, Iakoubov R, Brubaker PL (2009) GPR119 is essential for oleoylethanolamide-induced glucagon-like peptide-1 secretion from the intestinal enteroendocrine L-cell. Diabetes 58: 1058-1066. [Crossref]

12. Nakagawa-Yagi Y, Sato Y, Matsumoto E, Nakatsuka S, Sakaki T, et al. (2012) Pharmacological modulation of histone demethylase activity by a small molecule isolated from subcritical water extracts of Sasa senanensis leaves prolongs the lifespan of Drosophila melanogaster. BMC Complement Altern Med 12: 101. [Crossref]

13. Bhardwaj RS, Luger TA (1994) Proopiomelanocortin production by epidermal cells: evidence for an immune neuroendocrine network in the epidermis. Arch Dermatol Res 287: 85-90. [Crossref]

14. Petrovsky N (2001) Towards a unified model of neuroendocrine-immune interaction Immunol Cell Biol 79: 350-357. [Crossref]

15. Blalock JE (2005) The immune system as the sixth sense. J Intern Med 257: 126-138 [Crossref]

16. Briscoe CP, Tadayyon M, Andrews JL, Benson WG, Chambers JK, et al. (2003) The orphan $\mathrm{G}$ protein-coupled receptor GPR40 is activated by medium and long chain fatty acids. J Biol Chem 278: 11303-11311. [Crossref] 
Nakagawa-Yagi Y (2015) Discovery of a novel effect of electric field exposure on human plasma beta-endorphin and interleukin-12 levels: Insight into mechanisms of pain alleviation and defense against infection by electric field therapy

17. Pritchard LE, Turnbull AV, White A (2002) Pro-opiomelanocortin processing in the hypothalamus: impact on melanocortin signalling and obesity. $J$ Endocrinol 172: 411421. [Crossref]

18. Piomelli D, Sasso O (2014) Peripheral gating of pain signals by endogenous lipid mediators. Nat Neurosci 17: 164-174.

19. Fell GL, Robinson KC, Mao J, Woolf CJ, Fisher DE (2014) Skin $\beta$-endorphin mediates addiction to UV light. Cell 157: 1527-1534. [Crossref]

20. Khodorova A, Navarro B, Jouaville LS, Murphy JE, Rice FL, et al. (2003) Endothelin-B receptor activation triggers an endogenous analgesic cascade at sites of peripheral injury. Nat Med 9: 1055-1061. [Crossref]

21. Costanzi S, Neumann S, Gershengorn MC (2008) Seven transmembrane-spanning receptors for free fatty acids as therapeutic targets for diabetes mellitus: pharmacological, phylogenetic, and drug discovery aspects. J Biol Chem 283: 16269-16273. [Crossref]

22. Nakamoto K, Nishinaka T, Sato N, Mankura M, Koyama Y, et al. (2013) Hypothalamic GPR40 signaling activated by free long chain fatty acids suppresses CFA-induced inflammatory chronic pain. PLoS One 8: e81563. [Crossref]

23. Fujita T, Matsuoka T, Honda T, Kabashima K, Hirata T, et al. (2011) A GPR40 agonist GW9508 suppresses CCL5, CCL17, and CXCL10 induction in keratinocytes and attenuates cutaneous immune inflammation. J Invest Dermatol 131: 1660-1667. [Crossref]

24. Srivastava A, Yano J, Hirozane Y, Kefala G, Gruswitz F, et al. (2014) High-resolution structure of the human GPR40 receptor bound to allosteric agonist TAK-875. Nature 513: 124-127. [Crossref]

25. Lu SY, Jiang YJ, Lv J, Wu TX, Yu QS, et al. (2010) Molecular docking and molecula dynamics simulation studies of GPR40 receptor-agonist interactions. $J$ Mol Graph Model 28: 766-774. [Crossref]

26. Mizushige T, Saitoh K, Manabe Y, Nishizuka T, Taka Y, et al. (2009) Preference for dietary fat induced by release of beta-endorphin in rats. Life Sci 84: 760-765. [Crossref]

27. Salehi I, Sani KG, Zamani A (2013) Exposure of rats to extremely low-frequency electromagnetic fields (ELF-EMF) alters cytokines production. Electromagn Biol Med 32: 1-8. [Crossref]

28. Selmaoui B, Lambrozo J, Sackett-Lundeen L, Haus E, Touitou Y (2011) Acute exposure to $50-\mathrm{Hz}$ magnetic fields increases interleukin-6 in young healthy men. J Clin Immunol 31: 1105-1111. [Crossref]

29. Baldridge MT, King KY, Boles NC, Weksberg DC, Goodell MA (2010) Quiescen haematopoietic stem cells are activated by IFN-gamma in response to chronic infection. Nature 465: 793-797. [Crossref]

30. Williamson SA, Knight RA, Lightman SL, Hobbs JR (1988) Effects of beta endorphin on specific immune responses in man. Immunology 65: 47-51. [Crossref]

31. Ishikawa K (1929) Tuberculosis and physical therapy (in Japanese). In: J. Kawahara (ed.), Practice for clinical doctor - special issue on latest clinical tuberculosis, Daido Gakukan Press, Fukuoka, Japan, 1204-1209.

Copyright: (C2015 Nakagawa-Yagi Y. This is an open-access article distributed under the terms of the Creative Commons Attribution License, which permits unrestricted use, distribution, and reproduction in any medium, provided the original author and source are credited. 